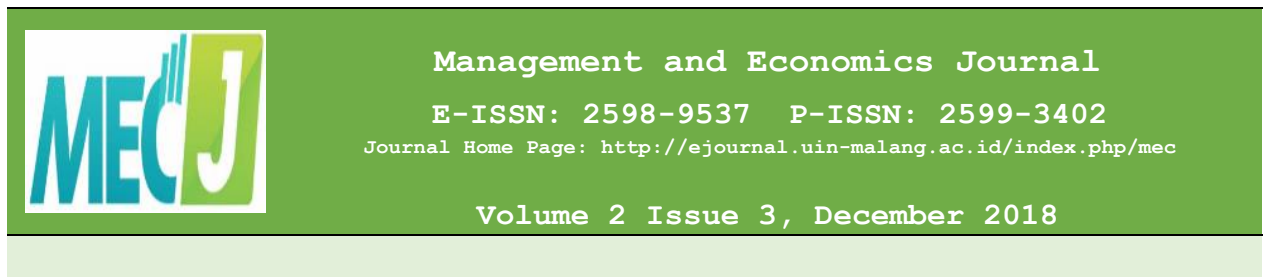

\title{
JOB SATISFACTION IN COMPENSATION, ENVIRONMENT, DISCIPLINE, AND PERFORMANCE: EVIDENCE FROM INDONESIA HIGHER EDUCATION
}

\section{Pramana Saputra}

Faculty of Economic and

Business

Brawijaya University

Prama.saputra.@gmail.com

\section{Achmad Sudiro}

Faculty of Economic and Business

Brawijaya University

Dodi W. Irawanto

Faculty of Economic and Business

Brawijaya University

\begin{abstract}
Banking This research aims to examine the role of job satisfaction in compensation, environment, discipline, and performance in Indonesia Higher Education, exactly in State Polytechnic of Banjarmasin (POLIBAN). To examine the hypotheses and mediator variabel, this research used Partial Least Square (PLS). It found that of ten hypotheses tested, four hypeteses were negative and insignificant. In addition, the test of mediation, by PLS or Sobel test, also showed that Job satisfaction cannot mediate the relationship between compensation and performance. However, it can be a mediator for the relationship between environment or discipline and performance. These results confirmed and contradict to the previous studies conducted.
\end{abstract}

KEYWORDS: Job satisfaction, compensation, environment, discipline, and performance.

Received Oct 2018 | Accepted Nov 2018 | Available online Dec 2018 |

| DOI: http://dx.doi.org

\section{INTRODUCTION}

The problem of the low level of performance of the Civil Servants in Indonesia, simply, can be seen from the low level of attendance in the work units of each civil servant. This is evidenced by the Minister of Administrative Reform and Bureaucratic Reform, Yuddy Chrisnandi, that the low level of civil servant attendance is caused by low employee work discipline (Pattiasina, 2016). Whereas employee work discipline is an important measure in improving employee performance, because through work discipline, employees with awareness and willingness to comply with all company regulations and prevailing social norms (Hasibuan, 2002).

In addition, the low PNS work discipline that results in low levels of PNS attendance, low performance of civil servants can also be caused by technical aspects of culture or work systems that are less supportive, such as aspects of quality performance will be influenced by knowledge, ability, motivation, environment, leadership, organizational structure of choice of strategy, technology, organizational culture and organizational processes (Sayd, et al. 2016). In fact, according to Fauza and Wismantoro (2013) sometimes there is a lack of clarity in the main tasks and functions of an employee, such as a high workload (can be caused by a lack of staff, high workload, etc.), and a lack of service compensation for the high workload.

Furthermore, based on the Ministry of State Apparatus and Bureaucratic Reform (Kemen PAN-RB) in 2016 released a survey on the Performance of Civil Servants in Indonesia. From the results of the survey it was found that out of a total of $4,498,643$ civil servants in 
Indonesia, only $40 \%$ of civil servants had certain skills and expertise at work. Meanwhile, the remaining $60 \%$ of civil servants have administrative expertise. Based on the results of the survey it is clear why many unknown things about civil servants in carrying out their work, they are only monotonous in work, cannot innovate. Therefore, in the future civil servant recruitment must be improved, the needs of prospective employees must be in accordance with the formation so that the performance of civil servants in Indonesia can experience a significant increase.

Higher education is a service organization that relies heavily on Human Resources (HR) in achieving its goals (Arwildayanto, 2012). That is, universities need skilled and competent human resources. The success of an organization depends heavily on HR utilization activities, namely people who provide energy, creativity and enthusiasm for the organization and play an important role in the operational functions of the organization. Human resources must always be cared for, maintained, maintained and developed by the organization (Hasibuan, 2002; Dessler, 2000).

Odunlade (2012) shows the effect of compensation on job satisfaction, and job satisfaction influences performance. In addition, Waskiewicz (1999) also examined the effect of compensation on job satisfaction through performance. Sopiah (2013) and Salisu (2015) state that there is a relationship or influence between compensation, satisfaction and performance. Meanwhile, Yaseen (2013) also found the same results, namely the existence of a positive and significant influence between compensation and satisfaction. Kusuma (2012) and Sugiyarti (2012) with higher education objects also found the same thing, namely both partially and simultaneously, compensation affects employee performance. On the other hand, Mabaso and Dlamini (2017) also found that compensation is a factor that can affect employee satisfaction, but what is interesting in this study is that benefits (as part of the compensation dimension) have no effect on satisfaction. Maguongo, et al. (2015) shows different things, namely that compensation does not affect job satisfaction. The difference in findings is a gap in this study.

Regarding the work environment, Razak (2012) examined the effect of the work environment on job performance and satisfaction. This study found that the work environment has a positive and significant effect on employee performance. Meanwhile, Raziq and Maulabakhsh (2015), Jain and Kaur (2015), and Muguongo, et al. (2015) found a significant relationship between work environment and satisfaction. In another study, Oswald (2012) also managed to prove a significant relationship between the work environment and performance. Sugiyarti (2012) and Utomo (2014) in the same context have also succeeded in proving the existence of a strong influence between the work environment and employee performance. Another interesting research is the research conducted by Sofyan, et al. (2016), which found a different thing, namely that the work environment affects satisfaction, but does not affect employee performance. Meanwhile, research by Amiroso and Mulyanto (2015) also found that the work environment had no effect on employee performance, even though he had an influence on job satisfaction. This can be another gap (research gap) in this study.

Work discipline is a trait, behavior or deed that is in accordance with regulations, both written and unwritten (Nitimiharjo, 2008). Another opinion says that discipline is essentially a genuine obedience that is supported by the awareness to fulfill duties, obligations and behave accordingly according to the rules or norms that apply in a particular environment (Syarif, 2012).

Work discipline, empirically, affects performance (Tumilaar, 2015; Priyono, et al., 2015; Ebuara and Coker, 2012; Agussalim, et al., (2016). Furthermore, the same results are also shown in other studies that there is a strong relationship between work discipline and employee performance (Triyaningsih, 2014; Wulandari and Alamanda, 2012; and Utomo, 
2014). However, different things are found by Amiroso and Mulyanto (2015) who find that work discipline affects performance. but it does not affect satisfaction, as well as the findings of Sofyan, et al. (2016), in his research stated that work discipline has no effect on employee satisfaction and performance, and finally the findings of Luviansi, et al., (2012) who found that between work discipline, job satisfaction, and work performance have no significant relationship, this can also be another research gap, which must be proven in this study.

The personnel section is expected to be able to bridge between what the organization needs from employees and what is needed by employees. To bridge the information gap regarding various phenomena related to job satisfaction, it is felt the need for a study that discusses the problem. For this reason, this study will examine the effect of satisfaction factors on employee performance further. With hope, that with an understanding of the influence of job satisfaction well, employee job satisfaction will be fulfilled so that they can provide the best performance to the organization.

There are many studies that prove that job satisfaction is a determining factor for employee performance, including research conducted by abdulwahab (2015), Amiroso and Mulyanto (2015), Wahid (2015), Awan and Asghar (2015), Owusu (2014), Khan, et al. (2011). They have all succeeded in proving the existence of a relationship and the influence between satisfaction with employee performance both directly and indirectly. The same results are also shown in Syanputri's (2009) and Sugiyarti (2012) findings.

Job satisfaction topics related to performance have been widely debated in various literature. Zheng Gu, et al. (2009), Abdulwahab (2015), Odunlade (2012), Khan, et al. (2011) and Owusu (2014) showed a one-way effect between job satisfaction and performance, on the other hand Christen's findings (2006) showed the opposite after successfully showing a negative relationship between the effect of performance on job satisfaction, and Luviansi (2012) also showed different is that there is no significant relationship between job satisfaction and work performance.

Banjarmasin State Polytechnic (POLIBAN) is a state university located in Banjarmasin City which is engaged in Vocational Fields. As the only vocational state university in Banjarmasin, all employees are required to always provide excellent service to the community. By always providing the best service to the community, of course POLIBAN will continue to grow and increase and be able to compete with other higher education institutions. This is certainly not possible without the support of reliable human resources.

POLIBAN strives to provide quality education services. The quality of service provided is inseparable from the concept that puts Human Resources as a key element for organizational success. In creating quality human resources to manage the organization, a healthy and professional work environment is needed, so that compensation is needed, and a work environment conducive to achieving job satisfaction to achieve the goals of an organization.

POLIBAN as the object of research, one of which is due to the high demands of the community for universities that can create or provide graduates who are ready to compete in the world of work. In 2018 alone, there were around 50,000 more high school graduates from Kal-Sel who competed for 10,000 seats in ULM (Universitas Lambung Mangkurat) and 1,000 more for POLIBAN itself Ernawati, (Banjarmasin Post, 2018). Readiness to compete in the world of work can be proven by the high quality and competency possessed by POLIBAN graduates in the future. Therefore, this study will greatly assist the higher education institution as an evaluation and projection material to make future policies in the framework as one of the efforts in improving the performance of higher education as a whole in order to fulfill all existing demands. 


\section{LITERATURE REVIEW \\ Compensation}

Simamora (2006) argues, compensation is also all forms of financial returns, tangible services, and benefits that employees get as part of an employment relationship. Werther and Davis (1996) define compensation as what employees receive in exchange for their contribution to the company. Compensation is a reward for services provided by a company (organization) to its employees. Such compensation can be in the form of financial compensation and non-financial compensation.

Compensation is one of the main factors in human resource management in organizations. Compensation is very important for both parties, namely for employees and the organization itself, as a medium to attract attention, maintain, and motivate employees to work harder. Because compensation is one reason someone works. Compensation can also serve as the main cause of employee satisfaction (Mabaso and Dlamini, 2017). This statement is also supported by Ismail and Razak (2016) which states that compensation and remuneration are complex and multidimensional factors of job satisfaction in higher education institutions.

According to Simamora (2006), the system of giving compensation by the organization to its workers is influenced by various factors. These factors represent the challenge of each organization to determine the compensation policy for its workers. One of the ways in which the management of an organization or company, both public and private, in order to improve employee performance is by providing compensation in accordance with the appropriate standards in which the organization operates (Sopiah, 2013). This is done no other because compensation is one of the factors that most influence the level of satisfaction and behavior of employees (Jamil and Raja, 2012). In other words, the higher the compensation received, the higher the satisfaction will be felt by employees. Furthermore, the higher the level of employee satisfaction, the higher their performance will be.

The description related to the relationship between compensation and employee performance is supported by some empirical evidence that has been carried out by several researchers including Sopiah (2013) and Jamil and Raja (2012). Both results of the study found that compensation, both financial compensation and non-financial compensation affect employee performance.

Other empirical evidence proves that there is a significant influence between compensation and job satisfaction. This is supported by research conducted by Odunlade (2012), Sopiah (2013), Mabaso and Dlamini (2017), Salisu, et al. (2015), Yaseen (2013), Kusuma (2012) and Sugiyarti (2012). In Odunlade's research (2012) compensation and benefits can be the cause of employees having high levels of satisfaction. Meanwhile, Mabaso and Dlamini (2017); Maguongo, et al, (2015); and Salisu, et al. (2015) confirm that with good compensation, employees can work better. Meanwhile, Yaseen (2013) asserts that compensation factors such as salary or wages, recognition, promotion, good work, significantly influence the level of employee happiness. Some research findings confirm that job satisfaction can be caused by good compensation. Based on these studies, the following hypotheses are proposed.

Hypothesis 1: There is a significant influence between Compensation and Employee Performance

Hypothesis 2: There is a significant influence between Compensation and Job Satisfaction

\section{Work Environment}

Safe, comfortable and attractive working conditions are created if the environment around the workplace is safe and healthy. Healthy work environment regulation activities include noise regulation, workplace lighting, humidity and air temperature, service to employee needs, color usage, maintenance of environmental hygiene and provision of various facilities needed by employees, such as lavatories, dressing rooms and places of worship. 
In relation to improving employee performance, an analysis of the environment is very important to know because it relates to motivation, which in turn will improve overall employee performance.

There are two reasons why attention to working conditions is important according to Arnold and Feldman (1996), namely the need for comfort in doing work and their social relations outside the workplace. A comfortable and healthy environment is carried out by a company towards its employees on moral, legal and economic grounds. Morally, managers organize a safe, comfortable and healthy environment that can be caused solely by the basis of humanity. Managers carry out such actions to create a harmonious and conducive work environment. The business is also intended to reduce the likelihood of employees experiencing accidents that can cause suffering for employees and their families.

According to Jain and Kaur (2014), the physical work environment is all that is around the workplace that can affect employees both directly and indirectly. Physical work environment is the workplace of employees to carry out their activities. The physical work environment influences the morale and emotion of the work of employees. These physical factors include air temperature in the workplace, wide workspace, noise, density, and tightness. These physical factors greatly affect human behavior. The physical work environment is also a factor that causes employee work stress that affects work performance (Robbins, 2007). Non-physical work environment is all the circumstances that occur relating to work relationships, both relationships with superiors and relationships with subordinates of co-workers (Jain and Kaur, 2014).

The work environment, in general, can be another factor that can cause employee performance to improve. Workplace comfort, availability of job support facilities, harmonious atmosphere in the workplace and mutual respect between employees or superiors with subordinates are environmental factors or working conditions that can be a driving force for employees to work well (Raziq and Maulabakhsh, 2015 ) Some reasons related to why a company or organization must be able to pay attention to the work environment is because a comfortable work environment will create high productivity and lack of supporting facilities for work done will cause a significant decrease in employee performance (Jain and Kaur, 2014).

A high level of performance has a correlation with the high fulfillment of facilities and the creation of a good environment in the workplace. Therefore, a work environment that supports the overall implementation of work can encourage high employee performance both in quantity and quality (Razaq, 2012; Sugiyarti, 2012; Utomo, 2014). Razaq's findings (2012) relate to the findings of research conducted by Jain and Kaur (2014), namely that the work environment can create conditions where employees can work productively.

With regard to the relationship between the work environment and satisfaction, empirically this has been proven by Amiroso and Mulyanto (2015); Jain and Kaur (2014); and Raziq and Maulabakhsh (2015). In certain situations, the factor that most determines a person can feel that he really enjoys the work he does is that he feels suitable with his work environment (Amiroso and Mulyanto, 2015). Some of these studies have succeeded empirically to prove that the work environment can create employee job satisfaction. With a good work environment, employees feel happy and happy in completing their work. Based on the description, a hypothesis is as follows.

Hypothesis 3: There is a significant influence between the Work Environment and Employee Performance

Hypothesis 4: There is a significant influence between the work environment and job satisfaction.

\section{Discipline}

Discipline is an orderly condition in which people who join an organization are subject to existing rules with pleasure. Gordon gives an understanding of discipline as a condition or attitude that exists in all members of the organization who are submissive and obedient to 
the rules of the organization (Ebuara and Coker, 2012). Another opinion says, that discipline is essentially a genuine obedience that is supported by the awareness to fulfill the duty of duty and behave accordingly according to the rules or procedures that should apply in certain environments (Kasim, et al. 2016).

Work discipline is a factor that is also very important in improving employee performance. With the existence of systems and procedures that are applied to all employees, the organization tries to direct employees to support and succeed in achieving organizational goals. Because work discipline is a manifestation of employee awareness to manage, obey and implement organizational rules and procedures (Agussalim, et al. 2015). With the high awareness of these employees, the employee's performance will also automatically increase (Priyono, et al. 2015).

Research that supports the influence of work discipline on employee performance has been demonstrated by Agussalim, et al. (2016), Utomo (2014), Wulandari and Alamanda (2012), Triyaningsih (2014), which emphasized the existence of a positive and significant influence. Meanwhile, Priyono, et al. (2015) and Tumilaar (2015) found that with high work discipline, high job performance will be created by employees based on their own responsibilities and awareness. Meanwhile, Amiroso and Mulyanto (2015) in their findings also indicate that employee performance can be positively influenced by high employee work discipline.

Related to the influence between work discipline and satisfaction has been proven by Ebuara and Coker (2012). The research indicates that the recognition factor which is a motivating factor in complying and carrying out the work as expected can have a positive and significant effect on job satisfaction. Thus, the hypothesis that can be proposed in this study are:

Hypothesis 5: There is a significant influence between Work Discipline and Employee Performance

Hypothesis 6: There is a significant influence between work discipline and job satisfaction

\section{Job Satisfaction}

Job satisfaction is an important aspect in the practice of human resource management and organizational behavior. This is because job satisfaction can affect happiness, work morale, and employee motivation in increasing their productivity (Mabaso and Dlamini, 2017). High job satisfaction is highly expected because it relates to positive results and is a sign of a well-managed organization. Job satisfaction is also a measure of a sustainable human development process. In addition, job satisfaction is important for every organization because job satisfaction is a criterion for measuring organizational success in meeting the needs of its members. Job satisfaction is something that is very personal, meaning that you can feel only those concerned, and have the nature of not always being the same between people who are one with the other

Arnold and Fieldman (1996) define job satisfaction as job satisfaction is defined as the number of positive influences or feelings that a person receives from his job. When we say someone has high job satisfaction, we mean that the person likes and appreciates his work and feels happy with his job. Meanwhile, Owusu (2014) defines job satisfaction as the level of happiness of an employee towards his work in fulfilling all his desires and needs.

\section{H5: There is a significant influence between innovation and team performance}

\section{Performance}

Bernardin and Russel (1993) define performance as an acquisition record that results from the function of a particular job or activity over a certain period of time. Meanwhile, according to Mangkunegara (2009) performance is "the quality of work and quantity achieved by an employee in carrying out his duties in accordance with the time given to him. 
Hasibuan (2002) argues that there are many ways of measurement that can be used, such as savings, error rates and so on. Almost all ways of measuring performance take into account: quantity, quality and timeliness.

Several empirical studies that indicate the same things have also been done from one decade to the next, including those carried out by abdulwahab (2015), Amiroso and Mulyanto (2015), Khan, et al. (2011), Owusu (2014), Sofyan (2016), Wahid (2015), Zheng Gu, et al. (2009), and Syanputri (2009). The findings of these studies are almost all uniform that job satisfaction is positively and significantly influences employee performance.

Regarding to the reciprocal relationship between job satisfaction and employee performance can be seen in the study of Christen, et al. (2006). He clarified based on the psychological view that the more a person has a good performance in a company or organization, the higher the satisfaction of the work he does. Furthermore, the results of this study found that employee performance positively and significantly influenced job satisfaction. Based on the theoretical and empirical assumptions above, the following hypotheses are proposed:

Hypothesis 7: There is a significant influence between Job Satisfaction and Employee Performance

Some previous studies empirically have confirmed the positive and significant influence between compensation and employee performance as found by Sopiah (2013) and Jamil and Raja (2012). Furthermore, Odunlade (2012), Sopiah (2013), Mabaso and Dlamini (2017), Salisu, et al. (2015), Kusuma (2012), Sugiyarti (2012), and Yaseen (2013) have also justified that compensation also affects job satisfaction.

With regard to the direct influence between job satisfaction on employee performance, it has also been proven empirically by abdulwahab (2015), Amiroso and Mulyanto (2015), Khan, et al. (2011), Owusu (2014), Sofyan (2016), Wahid (2015), and Zheng Gu, et al. (2009). Departing from the previous research, it can be concluded that the influence that occurs between compensation and employee performance can occur directly or indirectly. Therefore, this study proposed a hypothesis.

Hypothesis 8: There is a significant influence between compensation and employee performance through job satisfaction

Empirical evidence from the findings of previous studies said that the work environment affects employee performance (Amiroso and Mulyanto, 2015; Jain and Kaur, 2014; Sugiyarti, 2012; Utomo, 2014; and Raziq and Maulabakhsh, 2015) and the work environment is also positive and significantly affect job satisfaction (Razaq, 2012; Jain and Kaur, 2014).

In connection with research related to the influence of satisfaction on employee performance can be found in research conducted by Abdulwahab (2015), Amiroso and Mulyanto (2015), Khan, et al. (2011), Owusu (2014), Sofyan (2016), Wahid (2015), and Zheng Gu, et al. (2009). These studies have succeeded in proving a positive and significant influence between job satisfaction and employee performance. Thus, the hypotheses that can be proposed here are:

Hypothesis 9: There is a significant influence between work environment and employee performance through job satisfaction

Several previous studies have confirmed that work discipline affects employee performance. This has been empirically proven by Agussalim, et al. (2016), Priyono, et al. (2015), Tumilaar (2015), Utomo (2014), Wulandari and Alamanda (2012), Triyaningsih (2014), and Amiroso and Mulyanto (2015). In the study, researchers found that employee performance can be improved through high work discipline. 
As for the relationship between work discipline and its effect on job satisfaction, it has been proven empirically by Ebuara and Coker (2012). In this study, it was emphasized that with someone behaving discipline in work, then psychologically the employee was satisfied with what he did.

The influence of job satisfaction on employee performance directly can be seen in detail in Abdulwahab's research (2015), Amiroso and Mulyanto (2015), Khan, et al. (2011), Owusu (2014), Sofyan (2016), Wahid (2015), and Zheng Gu, et al. (2009) which generally concludes that satisfaction can improve employee performance. Departing from the results of these studies, the hypothesis proposed is as follows:

Hypothesis 10: There is a significant influence between work discipline and employee performance through job satisfaction

Figure 1. Conceptual Framework

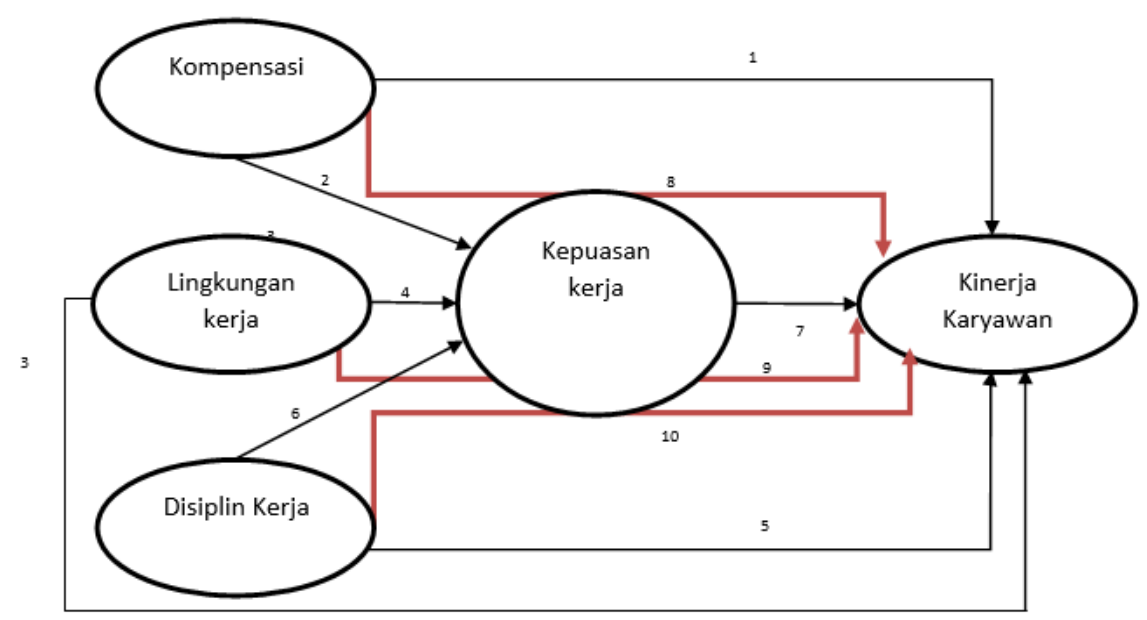

Source: Data Processed, 2017

\section{METHODS}

This research is classified as an explanatory research or commonly called explanatory research. This research was conducted at the State Polytechnic of Banjarmasin (POLIBAN) with the object of research of employees who have worked at least one year. the population in this study were the existing civil servants at the Banjarmasin State Polytechnic (POLIBAN) totaling 155 people. Data collection techniques used in this study are using questionnaires and personal interviews. Data analysis using PLS. PLS can be applied to almost all data scales, as a confirmation of theory, as structural modeling with indicators is reflective or formative. This is possible because the algorithm in PLS uses ordinary least square analysis so that the identification of the model is not a problem in the recursive model and does not assume a particular form of distribution of variable measurements. Furthermore, the efficiency of algorithm calculation is able to estimate large and complex models (Ghozali, 2006).

For measuring each variable, an indicator is used which is adapted by several theories that have been used by many researchers. Compensation variables consist of wages, incentives, benefits, and facilities (Odunlade, 2012). Meanwhile, for the work environment can be measured by the physical and non-physical environment (Jain and Kaur, 2014), 
work discipline can be seen from the presence, obedience and accuracy (Ebuara and Coker, 2012). Meanwhile, indicators for job satisfaction consist of the work itself, cooperation, promotion and supervision (Mabaso and Dlamini, 2017) and for employee performance consists of the quantity of work and quality of work (Jamil and Raja, 2012).

\section{RESULTS}

In the first data analysis, researchers examined instrument validity and construct reliability. To analyze instrument validity, it is said to be valid if the value of the loading factor is more than 0.6 and the value of Average Variance Extracted (AVE) is more than 0.5 for all variables. Meanwhile, discriminant validity is calculated using cross loading with valid indicator criteria in measuring the appropriate variables when the value of the loading factor in the variable matches more than the correlation value of the indicator on other variables. Whereas, for construct reliability or models can be achieved when the Cronbach alpha value and composite reliability is more than 0.6 and 0.7 (Chin, 1995). The results of testing the convergent validity of the variables in the study are presented in the following Table 1:

Table 1. Convergent Validity (Loading Factor)

\begin{tabular}{|c|c|c|c|c|}
\hline VARIABLE & INDICATOR & $\begin{array}{l}\text { LOADING } \\
\text { FACTOR }\end{array}$ & $\begin{array}{l}\text { CUT } \\
\text { OFF }\end{array}$ & INF. \\
\hline \multirow{4}{*}{$\begin{array}{l}\text { COMPENSATION } \\
\text { (X1) }\end{array}$} & X.1.1 & 0.742 & 0.6 & Valid \\
\hline & X.1.2 & 0.726 & 0.6 & Valid \\
\hline & X.1.3 & 0.752 & 0.6 & Valid \\
\hline & X.1.4 & 0.731 & 0.6 & Valid \\
\hline \multirow{2}{*}{$\begin{array}{l}\text { WORK } \\
\text { ENVIRONMENT (X2) }\end{array}$} & X.2.1 & 0.716 & 0.6 & Valid \\
\hline & X.2.2 & 0.907 & 0.6 & Valid \\
\hline \multirow{3}{*}{$\begin{array}{l}\text { WORK DISCIPLINE } \\
\text { (X3) }\end{array}$} & X.3.1 & 0.745 & 0.6 & Valid \\
\hline & X.3.2 & 0.747 & 0.6 & Valid \\
\hline & X.3.3 & 0.742 & 0.6 & Valid \\
\hline \multirow{4}{*}{$\begin{array}{l}\text { JOB SATISFACTION } \\
(\mathrm{Z})\end{array}$} & Z.1 & 0.810 & 0.6 & Valid \\
\hline & Z.2 & 0.808 & 0.6 & Valid \\
\hline & Z.3 & 0.807 & 0.6 & Valid \\
\hline & Z.4 & 0.749 & 0.6 & Valid \\
\hline \multirow{2}{*}{$\begin{array}{l}\text { EMPLOYEE } \\
\text { PERFORMANCE (Y) }\end{array}$} & Y.1 & 0.673 & 0.6 & Valid \\
\hline & Y.2 & 0.909 & 0.6 & Valid \\
\hline
\end{tabular}

To know the reliability of construct there are some testing that is discriminant reliability $(A \vee E)$, cronbach alpa and composite reliability. The criteria for each of these tests are constructively reliabel constructed if discriminant reliability (AVE) has a value greater than 0.5 , cronbach alpha is greater than 0.6 , and composite reliability is greater than 0.7 . The results of discriminant reliability (AVE), cronbach alpha, and composite reliability can be seen in Table 2.

Table 2. Cronbach Alpha and Composite Reliability

\begin{tabular}{lccccccc}
\hline \multicolumn{1}{c}{ VARIABLE } & AVE & $\begin{array}{l}\text { CUT } \\
\text { OFF }\end{array}$ & $\begin{array}{c}\text { CRONBACH } \\
\text { ALPHA }\end{array}$ & $\begin{array}{l}\text { CUT } \\
\text { OFF }\end{array}$ & $\begin{array}{l}\text { COMPOSITE } \\
\text { RELIABILITY }\end{array}$ & $\begin{array}{l}\text { CUT } \\
\text { OFF }\end{array}$ & INF. \\
\hline $\begin{array}{l}\text { COMPENSATION } \\
(\mathbf{X} 1)\end{array}$ & 0.514 & 0.5 & 0.874 & 0.7 & 0.893 & 0.7 & Reliabel \\
\hline WORK & 0.697 & 0.5 & 0.856 & 0.7 & 0.901 & 0.7 & Reliabel \\
\hline & & & & & & &
\end{tabular}


Job Satisfaction in Compensation, Environment...

\begin{tabular}{|c|c|c|c|c|c|c|c|}
\hline ENVIRONMENT (X2) & & & & & & & \\
\hline $\begin{array}{l}\text { WORK DISCIPLEN } \\
\text { (X3) }\end{array}$ & 0.549 & 0.5 & 0.838 & 0.7 & 0.879 & 0.7 & Reliabel \\
\hline $\begin{array}{l}\text { JOB SATISFACTION } \\
\text { (Z) }\end{array}$ & 0.582 & 0.5 & 0.904 & 0.7 & 0.917 & 0.7 & Reliabel \\
\hline $\begin{array}{l}\text { EMPLOYEE } \\
\text { PERFORMANCE }(Y)\end{array}$ & 0.590 & 0.5 & 0.766 & 0.7 & 0.850 & 0.7 & Reliabel \\
\hline
\end{tabular}

The table above explains that the AVE value of all variables is above 0.5 , namely, 0.514 compensation, 0.697 work environment, 0.549 work discipline, 0.582 job satisfaction, and 0.590 employee performance. Meanwhile, the Cronbach Alpha value for each variable is greater than 0.7 , namely 0.874 compensation, 0.856 work environment, 0.838 work discipline, 0.904 job satisfaction, and 0.766 employee performance. While for composite reliability value in each variable is greater than 0.7 , namely 0.893 compensation, 0.901 work environment, 0.879 work discipline, 0.917 job satisfaction, and 0.850 employee performance. This shows that all indicators have high reliability in measuring the latent variables.

Goodness of fit model is used to determine the ability of endogenous variables to explain the diversity of exogenous variables. In other words, to determine the magnitude of the contribution of exogenous variables to endogenous variables.

Tabel 3. Goodness of Fits Model

\begin{tabular}{lc}
\hline \multicolumn{1}{c}{ VARIABLE } & $\mathbf{R}^{2}$ \\
\hline EMPLOYEE PERFORMANCE & 0.619 \\
\hline JOB SATISFACTION & 0.189 \\
\hline Q2 $=\mathbf{1 - ( 1 - R 1 2 ) ~ X ~}(\mathbf{1}-\mathbf{R 2 2})$ & \\
\hline Q2 $=\mathbf{1 - ( 1 - 0 . 6 1 9 ) ~ X ( 1 - 0 . 1 8 9 )}$ & \\
\hline Q2 $=\mathbf{1 - 0 . 3 0 8}$ & \\
\hline Q2 $=\mathbf{0 . 6 9 1}$ &
\end{tabular}

Source: Data process (2018)

R2 employee performance variables have a value of 0.619 or $61.9 \%$. This shows that employee performance variables are able to be explained by compensation, work environment, work discipline, and job satisfaction variables by $61.9 \%$. Meanwhile, the remaining $38.1 \%$ is the contribution of other variables that were not part of this study.

$\mathrm{R} 2$ variable job satisfaction has a value of 0.189 or $18.9 \%$. This shows that the variable job satisfaction can be explained by the compensation variable, work environment, and work discipline by $18.9 \%$. Meanwhile, the remaining $81.1 \%$ is the contribution of other variables that were not part of this study.

Q2 (Q-Square Predictive Relevance) this study is valued at 0.691 or $69.1 \%$. This also means that the diversity of employee performance variables can be explained by the overall model by $69.1 \%$ or in other words the contribution of compensation, work environment, work discipline, and job satisfaction to employee performance is $69.1 \%$, while the remaining $30.9 \%$ is the contribution of other variables that are not a concern in this study.

To test and find out whether there is a relationship or influence between variables developed in the model that is the influence of exogenous variables on endogenous variables. Testing the hypothesis here is based on the value of t-Statistics, where the test criteria are if the value of t-Statistics (t-Calculate) is greater than t-Table (1.96), then shows a significant effect. The results of testing the hypothesis obtained based on the PLS model that is formed can be explained in the path diagram as follows: 
Figure 2. Path Diagram

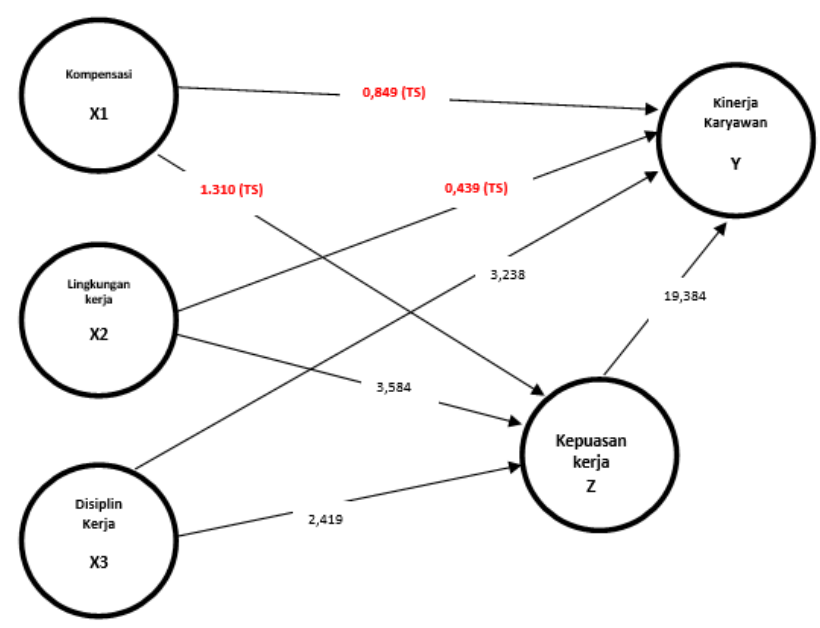

Source: Data process (2018)

Based on the path diagram above it can be seen that from the relationship of the five variables in the model, the relationship or influence between compensation (0.849) and work environment (0.439) on employee performance is insignificant. This happens because all the t-statistics values of the relationships between these variables are smaller than t-Table 1.96. Meanwhile, the correlation between the influence of work discipline $(2,419)$ and job satisfaction $(19,384)$ on employee performance shows significant results. The value of the t-statistic relationship between these variables is greater than t-table 1.96. Meanwhile, for the influence of the work environment $(3,584)$ and work discipline $(3,238)$ on job satisfaction, all showed significant results. In contrast to this relationship, the correlation between compensation and job satisfaction shows an insignificant influence, namely with a smaller ratio of t-statistics and t-tables, $1,310<1.96$.

Tabel 4. Hypotheses Testing

\begin{tabular}{clcccc}
\hline HYPOTESIS & EFFECTS & COEFFICIENCE & $\begin{array}{c}\text { STD. } \\
\text { ERROR }\end{array}$ & $\begin{array}{c}\mathrm{t}- \\
\text { Statistik }\end{array}$ & INF. \\
\hline $\mathbf{1}$ & $\mathrm{X} 1 \rightarrow \mathrm{Y}$ & 0.049 & 0.057 & 0.849 & Insignificant \\
\hline $\mathbf{2}$ & $\mathrm{X} 1 \rightarrow \mathrm{Z}$ & 0.159 & 0.122 & 1.310 & Insignificant \\
\hline $\mathbf{3}$ & $\mathrm{X} 2 \rightarrow \mathrm{Y}$ & 0.019 & 0.044 & 0.439 & Insignificant \\
\hline $\mathbf{4}$ & $\mathrm{X} 2 \rightarrow \mathrm{Z}$ & 0.249 & 0.069 & 3.584 & Significant \\
\hline $\mathbf{5}$ & $\mathrm{X} 3 \rightarrow \mathrm{Y}$ & 0.134 & 0.055 & 2.419 & Significant \\
\hline $\mathbf{6}$ & $\mathrm{X} 3 \rightarrow \mathrm{Z}$ & 0.252 & 0.078 & 3.238 & Significant \\
\hline $\mathbf{7}$ & $\mathrm{Z} \rightarrow \mathrm{Y}$ & 0.717 & 0.037 & 19.384 & Significant \\
\hline $\mathbf{8}$ & $\mathrm{X} 1 \rightarrow \mathrm{Z} \rightarrow \mathrm{Y}$ & 0.114 & 0.087 & 1.317 & Insignificant \\
\hline $\mathbf{9}$ & $\mathrm{X} 2 \rightarrow \mathrm{Z} \rightarrow \mathrm{Y}$ & 0.179 & 0.049 & 3.614 & Significant \\
\hline $\mathbf{1 0}$ & $\mathrm{X} 3 \rightarrow \mathrm{Z} \rightarrow \mathrm{Y}$ & 0.180 & 0.052 & 3.486 & Significant \\
\hline
\end{tabular}

Source: Data process (2018)

Based on Table 4 above the profit of the results of each hypothesis in this study, which can be used to determine the relationship between positive and significant variables between 
variables and there is a positive and insignificant relationship. The table explains that out of the 10 hypotheses proposed, there are four rejected hypotheses, namely the influence on satisfaction and performance, discipline on performance, and indirect interaction on satisfaction through satisfaction. In addition, all hypotheses are accepted.

\section{DISCUSSION}

\section{Compensation, Job Satisfaction, and Employee Performance}

Regarding compensation, Mabaso and Dlamini (2017) stated that high employee motivation can be increased by the high compensation provided by the organization. Compensation provides benefits for both parties, namely for the organization itself and for employees. With compensation, companies or organizations can pay attention to, maintain, and motivate them to stay in the organization, and at the same time can encourage employees to work harder. Because basically, compensation is one of the reasons an employee works. In addition, compensation in an organization can also be a multidimensional factor that can encourage an employee to be motivated to do a better job (Ismail and Razak, 2016). Furthermore, Odunlade (2012) asserts that compensation can be a factor of success in an organization. From the results of the study, compensation does not affect the performance of the employee's performance is not appropriate or contrary to some previous studies that have been done by previous researchers, namely; Sopiah (2013), Jamil and Raja (2012) who have successfully conducted an empirical test of the relationship of compensation to employee performance. They found that financial compensation and non-financial compensation significantly affected employee performance. Meanwhile, Mabaso and Dlamini (2017), Maguongo, et al, (2015); and Salisu, et al (2015) also confirm that with good compensation, employees can work well.

But refuting the above studies, this research actually gives a different view regarding the absence of significant influence of compensation on performance. This is also evident from the R2 variable employee performance has a value of 0.619 or $61.9 \%$ which means there are still $31.9 \%$ of which variables are not yet known which are not included in this study that can give effect to the performance of employees in POLIBAN.

These results prove that there is no strong relationship between the two variables with a positive correlation, meaning that even though the $\mathrm{X} 2$ variable is high, the changes that occur in the $Z$ variable are not too significant. This also means that the existence of a high $\mathrm{X} 2$ variable, from several indicators, does not affect the $Z$ variable (along with its indicators).

Theoretically, Ismail and Razak (2016) state that compensation is one factor where employees can feel their needs are met. With the fulfillment of these needs, then naturally they will feel happy. So, in other words, compensation can be concluded to provide satisfaction to employees.

The findings in this study, regarding the absence of the effect of compensation on job satisfaction, contradicted the research conducted by Odunlade (2012), Sopiah (2013), Mabaso and Dlamini (2017), Salisu, et al (2015), Yaseen (2013), Kusuma (2012) and Sugiyarti (2012). They found that compensation can be the cause of employees having a high level of satisfaction.

Meanwhile, Yaseen (2013) asserts that compensation factors such as salary or wages, recognition, promotion, good work, significantly influence the level of employee happiness. Some research findings confirm that job satisfaction can be caused by good compensation. However, this research is in line with the findings of Maguongo, et al (2015), which in his research showed different things, namely that compensation does not affect job satisfaction.

The test results revealed that the variable job satisfaction was not proven to act as a mediator between compensation for employee performance and $\mathrm{H} 8$ was rejected. The results of this study contradict the previous research conducted by Sopiah (2013), Jamil and Raja (2012), Odunlade (2012), Mabaso and Dlamini (2017), Salisu, et al. (2015), Kusuma (2012), Sugiyarti (2012), and Yaseen (2013). They all succeeded in proving the 
direct and indirect effects of compensation on employee performance. However, this finding is in line with the findings of Maguongo, et al. (2015), which in his research found a different thing, namely that compensation does not affect job satisfaction

\section{Work Environment, Job Satisfaction, and Employee Performance}

the work environment does not have a significant effect on employee performance and $\mathrm{H} 3$ is rejected. physical work environment and non-physical work environment, will not have an impact on employee performance as seen in the quality of work and quantity of work. Workplace comfort, a harmonious atmosphere, and a close relationship at work and mutual respect between employees or superiors with subordinates are environmental factors or working conditions that can be a driving force for employees to work well (Raziq and Maulabakhsh, 2015). Jain and Kaur (2014) assert that a comfortable work environment will create high productivity and a conflict-filled work environment among employees will cause a significant decrease in employee performance.

But refuting the above studies, this research actually provides a different view regarding the absence of significant influence on the work environment on performance. This is also evident from the R2 variable employee performance has a value of 0.619 or $61.9 \%$ which means there are still $31.9 \%$ of which variables are not yet known which are not included in this study that can give effect to the performance of employees in POLIBAN.

However, on the contrary, the work environment has a positive and significant influence on job satisfaction. The role of the work environment towards job satisfaction, Amiroso and Mulyanto (2015) states that one of the most decisive factors that a person can feel that he really enjoys the work he does is that he feels that he fits his work environment. Raziq and Maulabakhsh (2015) also emphasized that the management of work relationships and emotional control in the workplace (work environment) is a factor that is a medium to motivate employees to feel satisfied with their work.

This finding, regarding the influence of the work environment on job satisfaction, is in accordance with research conducted by Amiroso and Mulyanto (2015); Jain and Kaur (2014); and Raziq and Maulabakhsh (2015) which state that the work environment has a significant effect on job satisfaction. Likewise, this research is in line with the findings of Sugiyarti (2012) and Khan, et al. (2011) who found that workplace conditions and relationships with colleagues influence job satisfaction. Even though the work environment is not conducive, with management allowing the existence of emergency kitchens described earlier, it gives job satisfaction to employees because they can use the facility.

The work environment affects employee performance. The results of this study are in line with previous research conducted by Amiroso and Mulyanto, (2015); Jain and Kaur, (2014); Sugiyarti, (2012); Utomo, (2014); and Raziq and Maulabakhsh, (2015) which prove the direct effect of the work environment on employee performance. Whereas, to influence the work environment positively and significantly affect job satisfaction (Razaq, 2012; Jain and Kaur, 2014). because of the direct relationship between the work environment and insignificant employee performance, and the indirect relationship between the work environment and performance is equally significant, according to Baron and Kenny (1986) in Ghozali (2006) the mediation is called Full mediation.

This explains that even though the work environment does not affect employee performance directly, it affects if through job satisfaction. It can be interpreted that with all the shortcomings in the work environment, there is still satisfaction in the environment so that ultimately can improve the performance of employees in POLIBAN.

\section{Work Discipline, Job Satisfaction, and Employee Performance}

Work discipline has a significant influence on employee performance and $\mathrm{H} 5$ is acceptable. With regard to the role of discipline in improving employee performance, Agussalim, et al. (2016) include that work discipline is a very important factor in improving employee performance. In addition, discipline is also one of the elements that play a major role in carrying out and running the organization's wheels (Priyono, et al., 2015). 
The results of this study, namely work discipline affect the performance of employees, in accordance with several previous studies that have been done by previous researchers, namely; Agussalim, et al. (2016), Utomo (2014), Wulandari and Alamanda (2012), Triyaningsih (2014), which emphasized the existence of a positive and significant influence between discipline and employee performance. Likewise with the findings of Priyono, et al. (2015) and Tumilaar (2015) who found that with high work discipline, high job performance will be created by employees based on their own responsibilities and awareness. The findings of this study also confirm the research of Amiroso and Mulyanto (2015) in their findings which also indicate that employee performance can be positively influenced by high employee discipline. However, the results of this study contradict the findings of Sofyan, et al. (2016) and Luviansi, et al., (2012) who found that work discipline does not affect employee performance.

This finding, namely work discipline has an effect on job satisfaction, in accordance with several previous studies that have been carried out by previous researchers, namely Luviansi, et al., (2012) who found that work discipline has a strong influence on increasing employee job satisfaction. Likewise, this finding is in line with Tumilaar's findings (2015) which also confirms the influence between discipline and employee job satisfaction.

However, this finding contradicts the findings of Amiroso and Mulyanto's (2015) study which found that the relationship between work discipline and job satisfaction was not significant. Furthermore, this finding is also not in line with the results of Ebuara and Coker's (2012) study which confirms that work discipline related to class attendance, supervisor supervision, does not affect lecturer satisfaction. Sofyan, et al. (2016) who found that work discipline had no effect on job satisfaction.

It is known that the variable job satisfaction is proven to play a role as a mediating variable between work discipline and employee performance and $\mathrm{H} 10$ is accepted.

These results indicate that job satisfaction is a predictor of the birth of employee performance. Through job satisfaction, employees can carry out their work properly and effectively, so as to facilitate the organization in improving its performance in order to achieve organizational goals. In other words, the more employees have high job satisfaction, the higher the potential performance of employees in helping the organization realize its goals.

The results of this study are consistent with previous studies conducted by Agussalim, et al. (2016), Priyono, et al. (2015), Tumilaar (2015), Utomo (2014), Wulandari and Alamanda (2012), Triyaningsih (2014), and Amiroso and Mulyanto (2015). In the study, researchers found that employee performance can be improved through high work discipline.

In this study, testing of mediation variables was also conducted to find out whether mediation in this study was complete mediation (complete / full mediation) or partial mediation. The results obtained are independent variables namely work discipline, have a positive and significant influence on the dependent variable, namely employee performance. Whereas, job satisfaction mediator variables also positively and significantly affect employee performance. Furthermore, due to the direct or indirect relationship between work discipline and employee performance are equally significant, according to Baron and Kenny (1986) the mediation is called partial mediation.

Partial mediation explains that from work discipline can improve employee performance both directly and through job satisfaction as mediation. This indicates that the work discipline in POLIBAN has been in accordance with Government Regulation No.53 of 2010 concerning PNS discipline in Article 3 stating the obligations that are indicators of discipline, one of which is entering work and complying with working hours. This finding is also in accordance with the findings of Ebuara and Coker (2012) who found that with a person behaving discipline in work, the employee psychologically feels satisfied with what he does. Supported by high job satisfaction, it will produce high employee performance in accordance with the findings of Christen, et al. (2006) which partially and simultaneously found that employee performance can be improved by high job satisfaction perceived by employees. 


\section{Job Satisfaction and Employee Performance}

The results of this study that job satisfaction has an effect on employee performance, in line with several previous studies that have been carried out by experts, such as Abdulwahab (2015), Amiroso and Mulyanto (2015), Khan, et al. (2011), Owusu (2014), Sofyan (2016), Wahid (2015), Zheng Gu, et al. (2009), and Syanputri (2009). The findings of these studies are almost all uniform that job satisfaction is positively and significantly influences employee performance. Furthermore, these findings are also consistent with the results of Sofyan, et al. (2016) and Christen, et al. (2006) which partially and simultaneously found that employee performance can be improved by high job satisfaction perceived by employees.

\section{CONCLUSION}

This study shows that there is no influence between compensation and performance. This is due to compensation that has been categorized as Possible Over skill which means that if compensation is increased further it will not improve employee performance even better. Therefore, POLIBAN Agencies can focus more on work environment variables and work discipline to improve employee performance. the effect of compensation on job satisfaction is also insignificant. The work environment in POLIBAN both physically and non-physically is equally important by employees, although in the case in POLIBAN this research focuses more on the inadequate physical environment to support the performance of employees so that they can contribute to the institution at an even better. Whereas for the work environment towards job satisfaction, it means that even though the work environment is less conducive, with management allowing the existence of emergency kitchen described earlier, it gives job satisfaction to employees because they can use the facility.

Work discipline has a significant effect on employee performance. This is certainly caused by a qualified supervision system from POLIBAN, from using fingerprint absences to coming and returning from POLIBAN. Discipline behavior in working and contributing to the progress of institutions that conducted in accordance with the applicable rules can certainly lead to a sense of satisfaction in working. Job satisfaction is proven to be used as a mediator for work environment variables and work discipline, while for mediation the compensation variable is not.

Mediation of job satisfaction for compensation for employee performance proved to have no effect either partially or simultaneously. Meanwhile, the mediation of job satisfaction for the work environment towards employee performance has proven to have a significant effect and full mediation which means that the work environment can improve employee performance only through job satisfaction. Finally, the mediation of job satisfaction for work discipline on employee performance proved to have a significant effect and Partial Mediation or partial mediation which means that work discipline can improve employee performance both partially and simultaneously.

\section{REFERENCES}

Amabile, T. 1996. Assessing the Work Environment for Creativity. Academy of Management Journal, 39 (5), 1154-1184.

Abdulwahab. 2016. The relationship between job satisfaction, job performance and employee engagement: An explorative study. Issues in Business Management and Economics. Vol. 4, No. 1. Pp.1-8.

Agussalim, M. Putri, Ayu Rezkiana dan Ali, Hapzi. 2016. Analysis Work Discipline and Work Spirit toward Performance of Employees (Case Study Tax Office Pratama Two Padang). International Journal of Economics and Research. Vol, 13. No, 6. Pp. 2541-2556. 
Amiroso, Jajang dan Mulyanto. 2015. Influence of Discipline, Working Environment, Culture of Organization and Competence on Workers' Performance through Motivation, Job Satisfaction (Study in Regional Development Planning Board of Sukoharjo Regency). European Journal of Business and Management. Vol.7, No.36. pp. 86-95.

Arnold, Hugh J. Fieldman, Daniel. C. 1996. Organizational Behavior. Singapore: McGraw Hill Book Co.

Asman Abnur. Wawancara Hasil Survey Kinerja PNS Tahun 2016. http://www.jpnn.com/news/inilah-data-hasil-survei-kinerja-pns-tidak-mengejutkanya (Diakses pada Sabtu, 9 September 2017).

Awan, Abdul Ghafoor dan Asghar, Iffat. 2014. Impact of Employee Job Satisfaction on their Performance. A Case Study of Banking Sector in Muzaffargarh District, Pakistan. Global Journal of Human Resource Management. Vol.2, No.4, pp.7194.

Bangwal, Deepak. Tiwari, Prakash dan Chamola, Pankaj. 2017. Workplace Design Features, Job Satisfaction, and Organization Commitment. Journal of workplace rights. Pp. 1-12.

Bernardin, John H and Russel, Joyce E. A. 1993. Human Resources Management An Experiental Approach. Singapura: McGraw-Hill, Inc.

Brahmasari, Ida Ayu dan Suprayitno, Agus. 2008. Pengaruh Motivasi Kerja, kepemimpinan, dan Budaya Organisasi terhadap Kepuasan Kerja Karyawan serta dampak-nya pada Kinerja Perusahaan; Jurnal Manajemen dan Kewirausahaan, vol. 10, no 2, september 2008, hal 124-135.

Brown, Steven and Peterson, Robert. 1993. Antecedents and Consequences of Salesperson Job Satisfaction: Meta-Analysis and Assessment of Causal Effects. Journal of Marketing Research, Vol 30 No 1.pp.63-77.

Christen, Marcus. Iyer, Ganesh, and David, Soberman, 2006, Job Satisfaction, Job Performance and Effort: A Reexamination using Agency Theory. Journal of American Marketing Association Vol 70 (Januari 2006), p.137-150.

Deluca, Matthew J. 1990. Handbook of Compensation Management. New Jersey: Prentice Hall, Inc.

Dessler, Gary. 2000. Human Resource Management 8th Edition. New Jersey: Prentice-Hall, Inc.

Ebuara, Victor Obule. 2012. Influence of Staff Discipline and Attitude to Work on Job Satisfaction Lecturers in Tertiary Institutions in Cross River State. Public Policy and Administration Research. Vol 2. No. 3. Pp. 25-33.

Ghozali, Imam. 2006. Structural Equation Modeling: Metode Alternatif dengan Partial Least Square. Edisi ketiga. Semarang, Penerbit BP Universitas Diponegoro.

Gitosudarmo, Indriyo. 2000. Manajemen Pemasaran. Yogyakarta: BPFE.

Handoko, T Hani, 2006. Manajemen Personalia dan Sumberdaya Manusia. Edisi ke-2. Penerbit BPFE, Yogyakarta.

Ismail, A. and M.R. Abd Razak, 2016. A study on job satisfaction as a determinant of job motivation. Acta Universitatis Danabius, 12: 30-44.

Jain, Ruchi and Kaur, Surinder. 2014. Impact of Work Environment on Job Satisfaction. International Journal of Scientific and Research Publications. Volume 4, Issue 1. Pp.1-8.

Jamil, Bilal. 2011. Impact of Compensation, Performance Evaluation and Promotion Practices on Government Employees Performance VS Private Employees. Interdisciplinary Journal Of Contemporary Research In Business, Vol. 3, No. 8, December 2011.

Jogiyanto. 2007. Metodologi Penelitian Bisnis: Salah Kaprah dan Pengalamanpengalaman. Edisi 2007. Yogyakarta, Penerbit BPFE.

Judge T.A Picolo, 2008, Validity of the Dimensions, of the Fay Satisfaction Questioner Evidence of Differential Prediction. Personal Physiology Vol. 46 pp. 331-355. 
Khan, Alamdar Hussain. Nawaz, Muhammad Musarrat. Aleem, Muhammad and Hamed, Wasim. 2012. Impact of job satisfaction on employee performance: An empirical study of autonomous Medical Institutions of Pakistan. African Journal of Business Management. Vol. 6, No. 7. pp. 2697-2705.

Kusuma, Marhaendra. 2012. Pengaruh Gaya Kepemimpinan Partisipatif, Kompensasi, dan Motivasi terhadap Kinerja Karyawan di Sekolah Tinggi dan Politeknik Cahaya Surya Kediri. Jurnal IImu Manajemen, Revitalisasi, Vol. 1, Nomor 3. Pp. 1-12.

Luthans, Fred, 2009. Organizational Behavior. Ninth Edition. Singapore: McGraw Hill International Editions.

Luviansi, Melti. Djalil, Abdul. Sambung, Roby. 2012. Analisis Pengaruh Motivasi terhadap Prestasi Kerja melalui Kepuasan dan Disiplin Kerja Pegawai (Studi Pada Universitas Palangka Raya). JSM (Jurnal Sains Manajemen), Volume I, Nomor 1. Pp. 98-112.

Mabaso, Calvin Mzwenhlanhla and Dlamini, Bongani Innocent. 2017. Impact of Compensation and Benefits on Job Satisfaction. Research Journal of Business Management. Vol. 11, No. 2. Pp. 80-90.

Mangkunegara, A.A Anwar Prabu, 2009. Evaluasi Kinerja SDM, Refika Aditama, Bandung.

Mangkunegara, A.A.Anwar Prabu. 2009. Manajemen Sumber Daya Manusia Perusahaan. Edisi 1. Bandung: PT. Remaja Rosdakarya.

Manullang. 1992. Manajemen Personalia. Jakarta: Ghalia Indonesia.

Martoyo, Susilo. 2000. Manajemen Sumber Daya Manusia. Yogyakarta : BPFE.

Mathis Robert $L$ dan Jackson John H. 2002. Human Resoursce Management, Alih Bahasa. Jakarta: Salemba Empat.

Mathis, Robert L. dan Jackson, John H. 2006. Human Resource Management, alih bahasa. Jakarta: Salemba Empat.

Muguongo, Mary Makena. Muguna, Andrew T and Muriithi, Dennis K. 2015. Effects of Compensation on Job Satisfaction among Secondary School Teachers in Maara Sub-County of Tharaka Nithi County, Kenya. Journal of Human Resource Management. Vol. 3, No. 6. pp. 47-59

Nawawi, H. 2001. Manajemen Sumber Daya Manusia. Yogyakarta: Gadjah Mada University Press.

Nawawi, Hadari. 2000. Administrasi Personel Untuk Peningkatan Produktivitas Kerja. Jakarta: Haji Intermedia.

Nitisemito, Alex S., 2001. Manajemen Personalia. Jakarta : Ghalia, Indonesia.

Odunlade, R.O. 2012. Managing Employee Compensation and Benefits for Job Satisfaction in Libraries and Information Centres in Nigeria. Library Philosophy and Practice 2012.

Owusu, Benjamin. 2014. An Assessment of Job Satisfaction and Its Effect on Employees' Performance: A Case of Mining Companies in The (BibianiAnhwiaso-Bekwai District) In The Western Region. Thesis. Kwame Nkrumah University of Science and Technology.

Panggaben, Mutiara S. 2004. Manajemen Sumber Daya Manusia. Jakarta: Ghallia Indonesia.

Peraturan Pemerintah No. 46 Tahun 2011 tentang Penilaian Prestasi Kerja Pegawai Negeri Sipil

Peraturan Pemerintah No. 53 Tahun 2010 tentang Disiplin Pegawai Negeri Sipil

Peraturan Pemerintah Nomor 11 Tahun 2017 tentang Manajemen Pegawai Negeri Sipil

Prasetya, Arik and Kato, Masanori. 2011. The Effect of Financial and Non Financial Compensation to the Employee Performance. The 2nd International Research Symposium in Service Management. Yogyakarta

Priyono, Marzuki and Soesatyo, Yoyok. 2016. Influence of Motivation and Discipline on the Performance of Employees (Studies on CV. Eastern Star Home in Surabaya). 
Journal of Global Economics, Management and Business Research. Vol 5. No. 2. Pp. 212-220.

Razak, Arman Abdul. 2008. Work Environment Factors And Job Performance: The Construction Project Manager's Perspective. Construction Management Programme School of Housing, Building and Planning Universiti Sains Malaysia. Penang, Malaysia.

Raziq, Abdul and Maulabakhsh, Raheela. 2015. Impact of Working Environment on Job Satisfaction. Procedia Economics and Finance, 23. Pp. 717-725.

Robbins, Stephen P. 2007. Perilaku Organisasi. PT Indeks.

Sahari, Siti Huzaimah. Yusup, Mohd Yaman. Affidah, Morni. Aiza, Johari. 2013. Exploring Working Environment as a Stressor for Adult Students. Procedia-Social and Behavioral Science 101. Pp.564-574.

Salisu, Jamilu B. Chinyio, Ezekiel and Suresh, Subashini. 2015. The Impact of Compensation on the Job Satisfaction of Public Sector Construction Workers of Jigawa State of Nigeria. The Business and Management Review. Vol 6, No. 4. Pp. 282-296.

Sekaran, Uma and Bougie, Roger. 2010. Research Method for Business: A Skill Building Approach (Fifht Edition). United Kingdom, John Wiley \& Sons, Ltd.

Simamora, Henry, 2006. Manajemen Sumberdaya Manusia, STIE YKPN. Yogyakarta

Soehardi, Sigit. 2003. Esensi Perilaku Organisasional. Yogyakarta: BPFE UST

Sofyan, Muhammad. Rahman M, Abdul. Bima, Muh.Jobhar and Nujum, Syamsu. 2016. The Effect of Career Development and Working Discipline towards Working Satisfaction and Employee Performance in the Regional Office of Ministry of Religious Affairs in South Sulawesi. International Journal of Scientific and Technology Research. Volume 5, Issue 03. Pp. 51-57.

Solimun, Nurjannah, Adji Achmad Rinaldo. 2006. Pemodelan Persamaan Struktural Pendekatan Partial Least Square dan Structural Equition Modelling. Fakultas MIFA dan Program Pascasarjana Universitas Brawijaya Malang.

Sopiah. 2013. The Effect of Compensation toward Job Satisfaction and Job Performance of Outsourcing Employees of Syariah Banks in Malang Indonesia. International Journal of Learning and Development. Vol 3, No. 2. Pp.77-91.

Sudarno, Priyono, Sukmaningrum, Dinda. 2016. Effect of Compensation, Motivation and Organizational Climate on Employee Satisfaction: Study on PT. Sumber Alfaria Trijaya Tbk. in Gedangan-Sidoarjo. International Journal of Business and Management. Vol. 11. No. 2. Pp. 212-220.

Sugiyarti, Gita. 2012. Pengaruh Lingkungan Kerja, Budaya Organisasi dan Kompensasi terhadap Kepuasan Kerja untuk Meningkatkan Kinerja Pegawai (Studi Pada Fakultas Ekonomi Universitas 17 Agustus 1945 Semarang). Serat Acitya, Vol. 1, No. 2. Pp. 73-83.

Sugiyono. 2007. Statistika untuk Penelitian, Cetakan Kedua belas. Bandung, Penerbit Alfabeta.

Surat Edaran Kementrian Aparatur Negara dan Reformasi Birokrasi (Kemen PAN-RB) No. 02 Tahun 2013 tentang Pelaksanaan Penilaian Prestasi Kerja PNS.

Syanputri, Firstri. 2009. Analisis Pengaruh Kepuasan Kerja terhadap Kinerja Tenaga Kependidikan (Studi Kasus: Sembilan Fakultas Institut Pertanian Bogor, Darmaga Bogor). Skripsi. Fakultas Ekonomi dan Manajemen, IPB.

Tambunan, Tulus. 1996. Kunci Menuju Sukses Dalam Manajemen dan Kepemimpinan. Bandung: Armico.

Triyaningsih, SL. 2014. Analisis Pengaruh Disiplin Kerja, Motivasi Kerja dan Komitmen Organisasi terhadap Kinerja Karyawan Universitas Slamet Riyadi Surakarta. INFORMATIKA. Vol 1. No.2. Pp. 31-38.

Tumilaar, Brigita Ria. 2015. The Effect of Discipline, Leadership, and Motivation on Employee Performance at BPJS Ketenagakerjaan Sulut. Jurnal Riset Ekonomi, Manajemen, Bisnis dan Akuntansi (EMBA). Vol 3, No. 2. Pp. 787-797. 
Utomo, Bangun PC. 2014. Pengaruh Kepemimpinan, Motivasi Kerja, Disiplin Kerja dan Lingkungan Kerja terhadap Kinerja Karyawan dan Dosen STMIK Duta Bangsa Surakarta. Jurnal Sainstech, Vol. 1 No. 1. Pp. 13-24.

Wahid, Abdul. 2015. Impact of Job Satisfaction on Employees Performance an Application on Faculty of Science and Humanity Studies University of Salman Bin Abdul-Aziz-Al Aflaj. International Journal of Innovation and Research in Educational Sciences. Volume 2, Issue 1. Pp. 26-32

Waskiewicz, Stanley. 1999. Variables That Contributes to Job Satisfaction of Secondary School Asistant Principals. Dissertation. Virginia Polytechnic Institute and State University. Virginia.

Werther, William B and Davis, Keith. 1996. Human Resources and Personel Management. Boston: McGraw Hill, Inc.

Wexley, Kenneth N. And Gary A. Yukl. 1998. Organizational Behavior and Personnel Psyhology, Firt Edition. Illinois: Richard D. Irwin.

Wulandari, Astri. Alamanda, Dini Turipanam. 2012. Pengaruh Pelatihan dan Disiplin Kerja Terhadap Kinerja Karyawan Pada Yayasan Pendidikan Telkom. Jurnal Banking dan Manajemen Review Ekuitas, Vol. 1, No. 1. Pp. $12-24$.

Yaseen, Ayesha. 2013. Effect of Compensation Factors on Employee Satisfaction- A Study of Doctor"s Dissatisfaction in Punjab. International Journal of Human Resource Studies. Vol 3, No. 1. Pp. 142-157.

Zheng Gu, Ricardo Chi Sen Siu. 2009. "Drivers of job satisfaction as related to work performance in Macao casino hotels: An investigation based on employee survey". International Journal of Contemporary Hospitality Management, Vol. 21 Iss: 5 pp. $561-578$. 
